\title{
Spouses' Party Autonomy in the Regulations of Marital Relations, According to the Albanian Legislation
}

\author{
MA. Eniana Qarri \\ Lecturer, Law Faculty, University of Tirana \\ eniana-qarrihotmail.com
}

Doi:10.5901/mjss.2014.v5n27p137

\begin{abstract}
In this paper will be analyzed the recognition and guaranteeing of the principle of spouses party autonomy in the field of regulation of property and personal non-property relations between them. Based on the regulation of marriage in the Albanina Family Code provisions, it is undeniable that the principle of party autonomy is well known in the context of marital relationships, especially marital property regime, relations which in the past have traditionally been excluded from the scope of party autonomy. However, because of the family social importance and in order to balance spouses' private interests with the public interest, the spouses' party autonomy, in the regulation of the matrimonial property regime is limited in comparison with that of other contractual relationships, through non-derogable legal norms. Through the method of analysis of family law legislation and comparison with the previous legislation, the aim of this paper is exactly the study of the interaction between the non-derogable legal framework and spouses' autonomy in the self-regulation of their property interests.
\end{abstract}

Keywords: party autonomy, marriage, matrimonial property regime, marriage contracts, default regime, community regime, separate property regime.

\section{General Overview of the Party Autonomy Principle in the Regulation of Marital Relations}

In the context of new developments of family law in Albania, with the adoption of the new Family Code of $2003^{1}$, it is now perfectly acceptable to talk about recognizing and guaranteeing the principle of spouses' party autonomy in the regulation of relations between them, which together with the principle of spouses moral and legal equality are the basic principles of the regulation of marriage in the Albanian legislation. While in the communist regime the legislation in the area of family relations has been excluded from the will of the parties ${ }^{2}$, nowadays the principle of spouses' party autonomy is widely accepted in the doctrine and judicial practice. From a brief historical overview of the family relations in Albania, it can be said that in the past 50 years, family law was characterized by a clear lack of the autonomy of spouses to self-regulate their property interests. Property relations between spouses were regulated by mandatory provisions, without giving spouses the opportunity to change them through agreement. The legal property regime as the only available regime for the regulation of spouses' property relations was the "quasi-universal" joint ownership regime. It should be noted that this default regime was fully in line with the economic and social principles on which it was built the Albanian state and society, principles which were relied on state property and the elimination of private property.

It is important to note that spouses' party autonomy in terms of property regulations between them, was nonexistent in the Civil Code of 1981, under which the property of spouses would be subject in an obligate manner, of the joint ownership regime as a default regime ${ }^{3}$, eliminating any willingness of the spouses in this regard. Furthermore, the quasi universal community regime provided by this Code was a regime based on an excessive personal and property solidarity of the spouses, providing that any property acquired during the marriage, with the exception of assetas that are strictly for personal use, was jointly owned by both spouses (Articles 86 and 87 of the Civil Code of 1982).

Nowadays, considering already closed the debate on accepting whether or not the will of the spouses in the regulation of their property relations, the problems that arise for law scholars, refer to the demarcation and modalities within which this autonomy can be exercised by spouses (Cubeddu, 2000). The main purpose of this paper is exactly the study of the interaction between the non-derogable legal framework and spouses' autonomy in the self-regulation of their property interests.

${ }^{1}$ Hereafter we will refer to the Albanian Family Code of 2003 as the FC.

${ }^{2}$ See the Family Code of 1965, the Family Code of 1982 and the Civil Code of 1981 (Art. 86 and Art. 87).

${ }^{3}$ See Articles 86 and 87 of the Albanian Civil Code of 1982. 
Although, on one hand the legislator, in the current FC, has widened the scope of spouses party autonomy in the regulation of property relations, on the other hand, it has been careful in maintaining a minimum of solidarity among family members, through the regulation of the primary family regime (spouses material contribution to the costs and expenses of the family household, protection of the family dwelling and solidar liaility for the household debts), whose norms implementation are mandatory and unavoidable by agreement between spouses.

The principle of spouses' party autonomy is treated on the basis of a deep reform that has undergone the family law in Albania with the approval of the FC of 2003. This reform is in full compliance with the two basic principles of a democratic state, guaranteed by Article 11/3 and 18/1 of the Albanian Constitution, namely the principle of economic activity freedom, which is reflected in the FC, in the principle of spouses party autonomy in the sphere of regulation of their property interest; and the principle of legal equality, according to which spouses should be guaranteed the right to contract, as an opportunity to achieve equality before the law (De Paola, 1995). The legislator, in sanctioning the principle of party autonomy, in this reform, has been careful to maintain the balance between two principles of constitutional level, the protection of the family (Art. 53/3 of the Albanian Constitution) ${ }^{4}$ on one hand and individual freedom on the other hand, giving rise to family relationships, built on consensus and cooperation of the spouses (Anelli, 1998).

The concept of private autonomy is one of the most fundamental concepts of civil law, which generally finds definition as an opportunity for the self-regulation of the private interest. The possibility of interests self-regulation stems not ex novo from law, but it is only recognized and guaranteed by law (Russo, 1983), just as the Constitution guarantees the sovereignty of the people (Article 2 of the Constitution) or the human rights and fundamental freedoms (Article 15 of Constitution). Due to an essential importance, the limits of this autonomy remains to be determined, limits which will depend on the ratio between the public interest and the private interest of the family members.

Private autonomy of the spouses is limited in terms of regulation of personal non-property relations arising from the marriage. In this regard spouses can not eliminate (completely avoid) the mutual moral support, the obligation for cooperation in the interest of family and mutual support, the obligation of living together, because these obligations constitute the social meaning of marriage (Patti, 2012) and therefore they are provided with mandatory provisions in the FC. On the flip side, larger private autonomy spaces find place in the regulation of spouses property relations (Patti, 2012). Although spouses can not eliminate, neither by agreement their mutual economic contribution to the costs and expenses of the family household, they have the right to regulate the modalities of fulfilling this contribution.

In any case, the principle of private autonomy finds its broader expression in the matrimonial property regime 5 . Private autonomy of spouses in property relations finds its basis in the Article 66 of the Family Code, according to which the spouses have the freedom to decide for a different property regime from the default regime. Marriage contract is the remedy by which spouses, perform the autonomy granted by law for the self-regulation of their wealth interests.

\section{Spouses' Party Autonomy in the Regulation of Property Relations}

Based on the Article 66 of the Family Code, private autonomy manifests itself in the possibility of the future spouses to regulate their property regime with a contract, which may be concluded before or during the marriage, within the limitations prescribed in the provisions of the Family Code. Marriage contract represents the general rule in the regulation of spouses property relations and the legal community regime (default regime) will be applied, as an exception to the general rule, only in the absence of a marriage contract (Omari, 2010).

Private autonomy is firstly manifested in the selection of a contractor property regime between the several models offered by the law, thus excluding the application of the legal community regime (Patti, 2012). The Family Code provides three models of contractual property regimes: a) the community property contractual regime; b) the universal community regime, which accurately is a subcategory of community property regime and c) the separate property regime. Further, the principle of private autonomy manifests itself in the possibility of combining property regimes prescribed by law, for example: the combination of community legal regime and another contractual regime, under which a part of the property acquired during the marriage will be subject of the separate property regime, while the rest will be subject of any contractual regime chosen by the spouses, that may possibly be the legal community regime.

While, finally regarding the highest occurrence of private autonomy, the possibility of concluding an atypical contract (atypical property regimes enforcement) (De Paola, 1995), there is a high opinion divergence of various scholars in the field. Atypical property regime will means those regimes, which are not regulated by law, but their regulation is

\footnotetext{
${ }^{4}$ The protection of the family and marriage is expressed in Article 53 of the Albania Constitution.

${ }^{5}$ Matrimonial property regime means the totality of the legal norms, which have as their object the regulation of the property relations between the spouses during the marriage, and the relations between them and third parties. 
derived from the general principles of law, with only one limitation: these contracts must follow legitimate aims. The essence of this debate is to determine the limits of spouses' party autonomy in drafting atypical contracts, said in other words which are the principles that the parties must respect when they draft the contract content, which are the interests that the parties can attend which deserve to have the law protection (Russo, 1983).

Some authors are of the opinion, that the spouses possibility in matrimonial property regime regulation is limited to the field of property regimes prescribed by law (De Rubertis, 1975). According to this position, the spouses have the right to choose with a marriage contract, only one of the contractual property regimes regulated by law, or they may choose a combination of these regimes with the default community property regime (Patti, 2012). The argument that use this authors is that, the principle of contractual freedom (free determination of the contract content) shall not be applied to contract marriage because marital property regimes are only those provided explicitly by the legislator.

On the contrary, another group of authors assert, that even in the marriage contract, applies the principle of party autonomy (Article 660 of the Civil Code) as a result of which the spouses may choose to regulate atypical property regimes, not only in respect of the limits provided by law (Civil Code and Family Code), but also in respect of the principle of moral and legal equality of spouses. A marriage contract, which puts the spouses in a unequal moral position or unequal legal position, affirming the superior position or the reserved position of one spouse against the other one, is not valid (Oberto, 1999).

In our opinion, the position of the second group of authors is more acceptable and more logical if we analyze in its complexity and interaction not only the Family Code norms, but also the Civil Code norms. If we accept that the marriage contract is included in the general category of contracts, referred to Art. 660 of the Civil Code, the parties are free to determine the contents of the contract at their will, within the limits established by law. On the other hand, according to the Art.66 of Family Code, spouses property regime is regulated by law, in the absence of specific agreement of the spouses, in which they designate their own regime, which should not come in conflict with the code provisions and concerned legislation.

By a complementary analysis of the above two provisions of the Civil Code and Family Code, and based also on the fact that in the Family Code there is no provision that expressly prohibit atypical property regimes, we can conclude that spouses are free to apply any property regime prescribed or not by the law, which does not contradict at once with the mandatory provisions of the Family Code and those of the Civil Code.

In the final analysis, we should claim that spouses are free to regulate their property relations, through rules which in their entirety are not related to any typical contractual provided by FC (Salomone, 1997).

\section{Spouses Party Autonomy in the Regulation of Personal Non-Propery Relations}

Spouses party autonomy lies not only in their ability to self-regulate property relations, but also in the opportunity to express their will in the regulation of certain aspects of marital life, which include non-property content relationship, respecting their inevitable character and limits provided by the FC. Two elements are worth to be discussed in this case, within whose boundaries extend the spouses party autonomy and what is the legal nature and the qualification of these agreements.

It is worth mentioning, that the spouses party autonomy in terms of personal non-property relations is much more limited in relation to their freedom in the regulation of property relations. This limitation is understandable, given that due to the social role of the family in society, the public interest of family unity prevails over the private interests of the parties, the members who compose it. The principle of party autonomy in regulation of personal relations finds two limits, firstly the inevitable character of these obligations and secondly, the family interest (Patti, Cubeddu, 2011) as a principle of public order.

From a detailed reading of the Family Code provisions, it is obvious that spouses have the right to agree when they enter into a marrige, the surname that they will hold during the marriage, the common residence (family dweeling/home), the division of roles in the family, the children upbringing and education, and the marriage dissolution by mutual consent.

Based on Art.51 of the FC spouses are free to determine the surname they will hold during the marriage. It is understandable that the freedom to choose the surname is limited between two possibilities: a) spouses may keep as common surname, the surname of one of them, either the surmane of the husband or the wife, or b) spouses may keep the surname they had before entering into the marriage. So, the spouses can not choose to keep at the same time both their surnames. The choice of the surname has no time limitations, in this sense it can be realized at the moment the spouses enter into marriage, through the declaration before the civil registrar where the marriage enters into force, but it can be also changed even during the marriage, again with an agreement between the spouses.

The family dwelling which serves as a joint residence is another element of common life, to which the spouses 
have the right to decide on their own free will. Based on the Art. 55 of Family Code, the family dwelling of the spouses is chosed by mutual agreement. Defining a family dwelling, represents a typical example of what is traditionally understood as a limitation of personal freedom arising from the marriage. Each spouse is free to determine his dwelling, according to individual needs, but he/she should reach in a consistent consensus with his needs and those of the other spouse and children (Patti, Cubbedu, 2011).

In the absence of the possibility of reaching an agreement between the spouses, the law has found as the most appropriate solution, the intervention of the court (the inclusion of an auxiliary figure for spouses). In full accordance with the principle of legal equality of spouses, FC has determined that each of them has the right to settle the court to find a solution, in case of not reaching an agreement on the family residence. The court must reach a consensus solution, after hearing the opinion of both spouses and when it deems reasonable even the child opinion, who has reached the age of 14 years. If a consensus solution is not possible to be reached, the court decides what is the most appropriate solution for the family interests.

Although the scope of the marrige contract, referred to Art. 66 of the Family Code is the regulation of spouses property relations (choice of marital property regime), there is a possibility that spouses in the marriage contract include several clauses to regulate their personal relationships as mentioned above. In such a hypothesis, non-personal property relationships clauses, although they are reflected in the same text, they are not subject to the specific legal norms that are applied to the marriage contract (Russo, 1983).

\section{Non-Derogable Rights and Duties}

Spouses' party autonomy in the regulation of their property relations through the marriage contract instrument, is not unlimited. The principle of party autonomy is provided in the Art.66 of the Family Code and appearently it finds serious limitations in the Art. 67, 109/2 and 114/1 of the FC, and the restrictions provided in the Civil Code, which are applicable to all contracts.

In the identification of non-derogable rights and duties we should primarily individualize two typical contractual regimes, contractual community regime and separate property regime, each of which has its own non-deragable limits and also, to individualize those principles that are non-derogable for all the property regimes (Fusaro, 1990).

In addition to these, limits provided on the Civil Code provisions that are applicable to all the contracts, are also applicable to the marriage contract.

In summary of the foregoing analysis, the limits of spouses' party autonomy, referred to non-derogable rights and obligations, can be categorized into three groups: a) the limits provided in the Civil Code, applicable to all the contracts; b) the general limits applicable to all the matrimonial property regimes provided for in the Family Code and c) the specific limits provided for each contractual regime (Cubeddu, 2011). In this paper will be analysed only the limits provided for in the provisions of the Family Code.

\subsection{The general limits of Family Code}

From a combined analyse of the Family Code provisions, that regulate the marital property regime, we can conclude that the legislator has provided several restrictions, applied to any type of property regime chosen by the spouses. These limits can be summarized as follows:

A. Prohibition to avoid mutual rights and duties of spouses, as provided in the Title II of FC, (Art. 65), which, are considered public order provisions and may be subject to the spouses will, only in cases when the legal norms allows such a thing.

We recall that in the primary family regime are included family obligations like: the obligation to help and cooperation (Art. 50), solidar liability for common life and family dwelling debts (Art. 55), the obligation of surname holding (Art. 51), the obligation of material contribution to the costs and expenses of the family household (Art. 54), the obligation to children growth, upbringing and education (Art. 53), prohibition to possess family dwelling and its equipment without the consent of the other spouse, the right to free exercise and enjoy the profession and free disposition of professional income (Art. 63) 6 .

B. Impossibility to avoid the spouses rights and duties that derive from marriage (Art. 67, Family Code). Based on Art. 67 of the Family Code, the spouses can not evade rights and duties arising from the marriage. It

${ }^{6}$ These are unavoidable obligations, although in the case of liability of the surname, residence and material contribution, spouses have a wide margin of self-regulation, within the limits imposed by the FC. 
remains unclear what the legislator wanted to express with the rights and duties arising from marriage and why has it included this prohibition in a line with the provisions governing matrimonial property regime (Guerinoni, 2006). At first a glance it appears to be a duplication of Art. 65 of the Family Code, explained in the paragraph above, although on the other hand it would be nonsense the prediction of a legal prohibition on two different provisions. It should be well-understood which is the ratio of this legal prohibition, if the legislator had intended to include in the material sphere of application of Art. 67 only the rights and obligations of property character, or even personal non-property ones.

The legal doctrine has mostly estimated that, if the sphere of application of the norm are the personal nonproperty rights, then the norm is excessive, because the principle of inevitability of the spouses' personal rights and obligations is implied by all legislation that regulates family relations (Moscarini, 1989).

On the other hand, if the norm aim is to prevent the derogation of property character rights and obligations, this provision is inconsistent with the preceding, Art. 66 of FC, that under the principle of spouses' party autonomy allows the avoidance of the legal community regime, through the instrument of the marriage contract (Moscarini, 1989).

The italian legal doctrine stand is that the aim of the legislator has been the prohibition to derogate from those rights and obligations known as "onera matrimoni": moral and legal equality of spouses, common living obligation, the obligation of the moral and material support (material contribution), marital obligation of loyalty, cooperation in the interest of the family and cohabitation, the right to seek the marriage dissolution, and so on (De Paola, 1995).

On contrary, the french doctrine maintains that this prohibition refers primarily to the property rights and obligations arising from marriage, known as the "primary regime" of the family, but also includes personal nonproperty rights (Flour, Champenois, 1995).

On the other side, are not included on the material scope of application of the Art. 67 of the FC, the spouses' agreements, such as: a) in the field of personal non-property relations, the agreement for the family dweeling, the right of appointing the surname, the right to demand consensual divorce (De Paola, 1995); and b) in the area of property rights, the right to determine the modalities of the material contribution to meeting the needs of family?.

C. Impossibility to avoid parental responsibilities (Art. 67 of the Family Code). From the first reading of this provision, the impossibility to avoid parental responsibility seems unnecessary in this provision, because parental responsibility regulated under the Title III of the FC is realized with the mandatory provisions. When the legislator has aimed to give spouses the possibility to regulate the parental responsibility exercise by agreement between them, he has predicted this explicitly. Thus, for example, under Art. 221 of the the Family Code, if the parents do not agree on what child's best interest requires, they may address the court, which decides after it tries to resolve the matter amicably. From the interpretation of this provision, comes out that the parents right is recognized only to fix the modalities of parental responsibility exercise, always based on the best interests of the child, but the right to avoid parental responsibility exercise has not been granted.

D. Impossibility to avoid custody rules (Art. 67 of the Family Code). Even with regard to this legal prediction, we may use the same reasoning used above in relation to parental responsibility rules.

E. Impossibility to avoid the community regime administration rules (Art. 67 of the Family Code)

Spouses can not change by agreement between them the community regime administration rules, which are regulated by mandatory provisions in the FC. Rules of the legal community administration are particularly important to ensure the equality of the subjects (spouses) in their property relations. The regime of the administration of the community assets is based in the mutual consent of the spouses, for transaction of the assests.

F. Impossibility to avoid the dutie of the spouses to contribute to the costs and expenses of the family household (Art. 54 of Family Code). Spouses have the right to regulate through agreement the modalities of their material contribution for the costs and expenses of the family household, but they can not avoid the fulfillment of this obligation. It is void any contractual disposition that exclude one of the spouses from his/her dutie to contribute for the family needs. The contribution can be fulfill in money (materially) or in natyre.

G. The right to seek marriage dissolution or annulment (Finocchiaro, Finocchiaro, 1984) (Art. 214 of the Family Code). It is also void any contractual clause, which restricts the right of each spouse, to ask at any case the

\footnotetext{
${ }^{7}$ We recall that for all these rights, the law has recognized the spouses the right of self-regulation of their interests by agreement, within
} the legal limits. 
dissolution or nullity of the marriage.

H. The administration of the family dwelling, (Art. 57 of the Family Code). Based on the Art. 57 of the Family Code, the spouses can not dispose of the marital dwelling and its equipment without the consent of the other spuse, despite the marital property regime. From this analysis we conclude that, any transaction of family dwelling and its equipment, by one spouse without the consent of the other spouse is invalid, regardless of the marital property regime that spouses have chosen, legal community regime/contractual or separate property regime, irrespective of whether the dwelling is owned by both spouses or is in the personal ownership of only one of them. The spouse who has not consented to the action performed by the other spouse related to the marital dwelling, has the right to request the nullity of the contract, within one year from the date when he was informed about the performance of the action, but not later than 1 year from the date when the marital property regime was over.

\subsection{The specific limits of the marriage contract provided in the FC}

Specific or special limits are those limits of spouses party autonomy, which vary according to the property regime that spouses have choosen through agreement. In the category of the specific limits we can identify:

A. The spouses' personal assets (Art. 109/2 and Art. 114/1 of the FC). Despite which property regime the spouses have chosen, whether a partial or universal community regime, a certain category of assets will always remain in the personal property of the spouse who has acquired it, such as: the assests strictly used for personal use by each spouse and those assests acquired as accessories of personal property (article 77/c FC); working tools, which are necessary for the profession of one of the spouses, except those who are appointed for the administration of a commercial activity (Article 77/d FC); and the property acquired as a personal damage compensation, excluding income derived from pension rights gained due to the partial or full loss of the ability to work (Article $77 / \mathrm{d}$ of FC).

By reading "per a contrario" the Art.109/2 and Art.114/1 of FC, we can draw two important conclusions.

First, we conclude that the personal damage compensation (invalidity pension rights), as a result of partial or full loss of the work capacity and work tools required for the proffession of one spouse, that are assigned to the administration of a commercial activity, may be involved in the community and therefore it is under spouses will, who can decide to exclude them from the community, if it is reasonable for them.

Secondly, through interpretation "per a contrario", we notice that the property acquired as a personal property accessories, are also always subject to the personal property regime and consequently their regime can not be modified by spouses will, neither when they choose universal community property regime.

B. Prohibition of voluntary assets' division during the community regime. According to the Art. 97 of the the Family Code, the property division can not be realized during the exictence of the community regime, neither in case of an agreement between the spouses. From the attentive reading of this provision we make two conclusions.

Firstly, the prohibition of assets separation during the duration of the community, refers to the case when the matrimonial property regime is governed by the legal community, as well as the case where the spouses have chosen a different contractor community regime, whether universal community or modification of the legal community regime, or another atypical model, characterized by joint ownership. Also, we can be state, that this prohibition does not refer to the contractor regime of separate property, not only because it makes no sense to talk about the division of real property under the separate property regime, but because the legal provision itself, explicitly uses the term "community" .

Secondly, we conclude that the division of the community property assets can not be realized, neither by spouses agreement, nor by a court decision.

However, there is an exception in Article 98 of the Family Code for the prohibition mentioned above, which allows propertys division during the community existence if the spouses are in any of the three circumstances, expressly contemplated by this provision.

According to Article 98 of the Family Code, each of the spouses may request the court to demand the division of the property during the duration of the legal community/contractor regime only in case there is verified one of the three circumstances as below:

- Inability and mismanagement of the assets by one spouse, when the administration of the assets, has put at risk the interests of the other spouse or the interests of the family;

- One of the spouses does not contribute to the family's needs (cost and expences of the family household), in 
proportion to their status and ability to work;

- When there has ocurred an actual division of the community property.

It is the first instance court's juridiction the judgement of the case, while referring to territorially competence, it is the court of the place where the assets or most of them are placed ${ }^{8}$. The right to seek judicial division of the community property assets belongs to each of the spouses, personally or by their legal representatives. With the recognition of the legal representatives right to seek the property division, the law seems to refer to the case when the requesting spouse ability is removed / limited his to act upon the court verdict. In this case, the custodian of the spouse incapable of acting, who is his legal representative has the right to invest the court about the property division, if there is verified one of the legal requirements in the first paragraph of Article 98 of the Family Code. The problem that arises is the case when the custodian of the incapable of acting spouse is his own spouse. In this case the institute of special custody helps us, and consequently a special custodian will be assigned to the incapable spouse to act in order to represent his in the trial.

The law did not recognize spouses' creditors the right to seek the community property division.

The court's decision on the community property division brings two important consequences: firstly, the property division brings the end of the community regime, but not the marriage termination. It is the only case where the community regime ends due to the assets division, in other words it is the only case when the property division precedes and brings the community termination. Secondly, the cour puts spoust's decision put the spouses under the separate property regime for their future. The implementation of the separate property regime in this case represents an exception to the general rules, because it is the only case when this regime, turns from an optional regime to a default one.

\section{Conclusions}

In the final analysis, we should admit that the novelty brought by the current Albanian Family Code is the recognition of a broad party autonomy for spouses, in terms of regulation of their property relations, thus setting a contractual regime which will be applied for the property acquired by spouses during the marriage, and the possibility of adapting this regime with the family life dynamics (Lo Sardo, 1991). The spouses are etitled to make a contract regarding their matrimonial property regime, known as the "marriage contract" as a manifestation of their autonomy. The principle of spouses' party autonomy finds its justificaton in the necessity, in the context of the new economic relations of the society, to achieve nowadays the adaptation of the property regime with the property interest, not only of the family as a social entity, but also to the each individuals that constitute it (spouses), within the limits established by law (Terra, 2008). In order to facilitate the work of the spouses in the selection of the property regime that better suits their interests and to channel their contractual freedom, in the Albanian Family Code are provided several models of property regimes, which do not intend to limit the freedom of selecting the property regime, but only intend to guide it.

In any case the limits of private autonomy should be evaluated on the basis of the assessment and maintenance of balance between the interests of spouses, family members' interests and the interests of third parties (Cubeddu, 2000).

\section{References}

Anelli, F. (1998). Sull'esplicazione dell'autonomia privata nel diritto matrimoniale. In Studi in onore di P. Rescigno II (pp. 13-54). Milano: Giuffré Ed.

Cubeddu, M. G. (2000). Autonomia privata e regimi patrimoniali. In T. Auletta (Ed), I rapport patrimoniali tra coniugi III (pp. 1-26). Torino: Giappichelli Ed.

Cubeddu, M. G. (2011). Le convenzioni matrimoniali. In S. Patti \& M.G. Cubeddu (Eds.), Diritto di famiglia. Milano: Giuffré Ed.

De Paola, V. (1995). Il regime patrimoniale della famiglia. Tomo secondo. Milano: Giuffré Ed.

De Rubertis G. (1975). Le Convenzioni matrimoniali in generale. Vita Notarile. Studi, problemi e lettere del notariato. Palermo: Buttitta Edizioni Giuridice.

Finocchiaro, A., Finocchiaro, M. (1984). Diritto di famiglia, Commento sistematico della legge 19 Maggio 1975, n.151. Volume I. Milano: Giuffré Ed.

Flour, J., Champenois, G. (1995). Le régimes matrimoniaux. Paris: Armand Colin Ed.

Fusaro, A. (1990). II regime patrimoniale della famiglia. In F. Galgano (Ed.), I grandi orientamenti della giurisprudenza civile e commerciale. Padova: Cedam.

Guerinoni, E. (2006). I regimi patrimoniali convenzionali. La comunione convenzionale. In G. Cassano (Ed.), II diritto di famiglia nei nuovi orientamenti giurisprudenziali II. II regime patrimoniale della famiglia (pp. 332-360). Milano: Giuffré Ed.

Lo Sardo, G. (1991). La comunione convenzionale nel regime patrimoniale della famiglia. Rivista del Notariato. Milano: Giuffré Ed. 1211-

${ }^{8}$ According to Article 45/1 of the Civil Procedure Code, law suits for incorporeal rights over real property, for separation of assets in common and possession arise in court of the land where the assets or most of them are placed. 
1391.

Moscarini, L. V. (1989). Le convenzioni. In M. Bianca (Ed.) La comunione legale. Tomo II, (pp. 1003-1032). Milano: Giuffré Ed.

Oberto, G. (1999). I contratti della crisi coniugale. Milano: Giuffré Ed.

Omari, S. (2010). E drejtë Familjare. Tirana: Botimet Morava.

Patti, S. (2012). Regime patrimoniale della famiglia e autonomia privata. In A. Franco \& M. Sesta (Eds.), I/ regime patrimoniale della famiglia (pp. 3-28). Milano: Giuffré Ed.

Patti, S., Cubeddu, M.G. (2008). Diritto della famiglia. Milano: Giuffré Ed.

Russo, E. (1983). Le convenzioni matrimoniali ed altri saggi sul nuovo diritto di famiglia. Milano: Giuffré Ed.

Salomone, L. M. (1997). Lo sicoglimento della comunione legale dei conuigi. In G. Cassano (Ed.), II diritto di famiglia nei nuovi orientamenti giurisprudenziali II. II regime patrimoniale della famiglia. Milano: Giuffré Ed.

Terré, F., Simler, Ph. (2008). Droit Civil. Les regimes matrimoniaux. Paris: Dalloz. 